\title{
A Slow City Movement: The Case of Halfeti in Turkey
}

\section{Fatma Kürüm Varolgüneş Fatih Canan $^{* *}$}

\section{Abstract}

In today's world where globalization is increasing, many cities cannot ada pt to rapid changes. The changing lifestyles of the inhabitants of the city cause a rapid loss of urban differences and originalities. Several movements have emerged to solve these problems. One of these movements is the slow city movement proposed for a better environment and social life. The slow city movement sets out the parameters that ensure the viability of cities, which give importance to the continuity of the improvement of social, economic, cultural and environmental qualities. This movement, which strives for the preservation of originality against the impact of globalization, has a great importance in order to increase the quality of urban life.

Keywords: Halfeti, slow city movement "Cittaslow", SWOT analysis, Turkey

*Dr, Bingol University, Department of Architecture, Bingol, Turkey

E-mail: fkvarolgunes@bingol.edu.tr Orcid ID: http://orcid.org/0000-00023214-4274

**Asst.Prof.Dr., Konya Technical University, Department of Architecture, Konya, Turkey E-mail: fcanan@ktun.edu.tr Orcid ID: http://orcid.org/0000-00034469-1993

The aim of this work is to identify the strengths and weaknesses of sustainable development of the slow city declared places, and to identify the threats and opportunities that can be faced. In this way, targets and 
strategies for the sustainability of the desired criteria for cities declared as slow cities can be determined. In the study, environmental analysis and situation analysis were carried out by observation and inventory collection method in Halfeti province of Urfa declared as slow city. The local people and tourists who visited the area were interviewed and SWOT analysis was conducted by brainstorming method. The district of Halfeti consists of two regions. The old Halfeti area is a very old settlement; some of the buildings it contains are under the waters of the Euphrates, in the appearance of an open-air museum. The new Halfeti is a region formed with non-specific regulations and illegal and distorted building is seen intensively. With the declaration of Halfeti as a slow city, the tourism movements have begun to accelerate. As a result of this study, it has been determined that this region with historical and natural beauty has been caught unprepared for tourism development. For this reason, it is necessary to prioritize rehabilitation efforts in the region and prepare action plans for the new Halfeti settlement. The conclusion is that Halfeti's unique identity values should be promoted on a global scale and protected as cultural heritage. It is expected that the results obtained in the study will also be a road map for other slow cities similar to Halfeti.

\section{INTRODUCTION}

Today the effects of globalization is on rise in all over the world. Particularly the development and widespread use of mass communication tools and their accessibility by many people has made the world much smaller than before. This has affected life modes and trade exchanges in the world. As a result, societies have undergone changes in their way of life, especially in cities in developing countries. Many cities cannot adapt to rapid changes. The changing lifestyles of the urban people cause the rapid disappearance of the things that make a city original, authentic and unique. In order to solve these problems, various movements have been revealed. One of these movements is the slow city movement "Cittaslow", which is recommended for a better environment and social life. People seeking a different way of life rather than consumption-oriented life, which does not give happiness and peace, has revealed the Cittaslow movement in the urban scale. According to a definition, Cittaslow is an international network of small towns that combines urban planning and slowing cities in planning. The Cittaslow movement encourages societies to adopt slowness as a lifestyle. It also encourages food production using natural and environmentally friendly techniques. It is both a social movement and a model for urban governance; it emphasizes local distinctiveness in the context of globalization and seeks to improve the quality of life locally (Yllmaz, 2016). It aims to move away from fast models of urban design. In addition, some properties such as slow cities, slow food, 
slow life and slow travel depends on "slow" philosophy (Kamel, Orabi, \& Taha, 2017).

Cittaslow's main philosophy is to create an antithesis to the fast life. However, at the same time, it values ecology and sustainable development, which is nourished by locality and authenticity (Dickinson, 2009; Yurtseven \& Kaya, 2011). Slow city movement sets out the parameters that give importance to the continuity of the improvement of social, economic, cultural and environmental qualities and the viability of the cities. This movement, which strives to preserve authenticity against the influence of globalization, is a great way to increase the quality of urban life.

The slow city movement, which originated in Italy, was inspired by small and medium-sized towns in Italy. The infrastructure required for this movement to be functional should be provided. It is more important to stimulate local dynamics against external factors. In other words, instead of clone towns, it is tried to ensure the continuation of local township cities. Emphasis on local, regional and cultural awareness and the original values of cities is among the main objectives. In short, it can be said that living in cities that participate in the slow city movement will correspond to a higher urban quality of life. Because living in these cities means controlling environmental pollution, promoting local development means protecting traditional architecture, culture and traditional life style. There will undoubtedly be a high quality of life with the control of such problems.

\section{LITERATURE REVIEW}

Cittaslow means slow city and has recently emerged as a small network of international cities in Italy, addressing the philosophy of slow food in urban design and planning (Dickinson, 2009). Cittaslow philosophy advocates continuing to live at a pace that is enjoyable for life. The Cittaslow movement claims that cities that are self-contained, sustainable, protect crafts, nature, traditions and customs, but also have no infrastructure problems, where residents can communicate and socialize with each other, use renewable energy resources and benefit from technology are realistic alternatives (Cittaslow, 2018). Cittaslow towns introduce a place-based identity approach to their urban plans. Cittaslow has adopted the principle of encouraging local diversity and economic and cultural strengths, strength from historical sources and traditions, and a slow, comfortable living pace (Semmens \& Freeman, 2012). Paolo Saturnini (Mayor of GreveinChianti) founded Cittaslow in the year 1999. Saturnini saw the need to preserve the authenticity and properties of smaller urban regions (Miele, 2008). Cittaslow aims to preserve the quality of life 
integral to each city's sense of place, environmentally sustainable. The underlying philosophy is to identify and support each city region's assets and ways of life which have traditionally formed its identity (Radstrom, 2014).

The main purpose of the slow city movement is to protect the local and authentic identity of the cities and to improve the quality of urban life. Slow cities are trying to achieve this goal by controlling air, water, noise and light pollution, encouraging alternative energy resources and recycling, increasing green areas, protecting traditional architecture and lifestyle and strengthening local development. The cities who take part in Cittaslow movement endeavours to effect the following main principles: They mind public health, in this context, they care for procurement of healthy products and food; they encourage traditional handicrafts and valuable craft studies; they mind the structure of the city. In this context, they construct squares, theatres, shopping centers, coffee houses, and restaurants without harming the structure of the city; they are respectful to traditions, which provides a tranquil and peaceful atmosphere (Ekinci, 2014).

As a concept, Cittaslow focuses on improving the quality of life of local people rather than tourists. This can only happen if the local people embrace tranquillity. In this process, it is important that municipalities give importance to working together rather than prohibitions. Slow city philosophy encourages cities to identify areas of strength and weakness and to develop a strategy in this respect. Therefore, some criteria have been put forward to be a slow city. These criteria are presented in detail in Table 1. Cities with Cittaslow title are determined according to these criteria.

Slow city (Cittaslow) criteria serve as a road map for local governments wishing to reach a sustainable city. It encourages the development of projects in areas such as reducing carbon footprints of cities, making use of renewable energy sources, recycling, collecting waste oil and batteries and organizing energy saving campaigns (Göçkan, 2012). It is not expected that the city will be able to meet all of the slow city criteria at the moment. Cities are considered to need time to meet all of the slow city criteria. 
Table 1. The cittaslow criteria (Source: Charter, 2018; Doyduk \& Okan, 2016; YIlmaz, 2016)

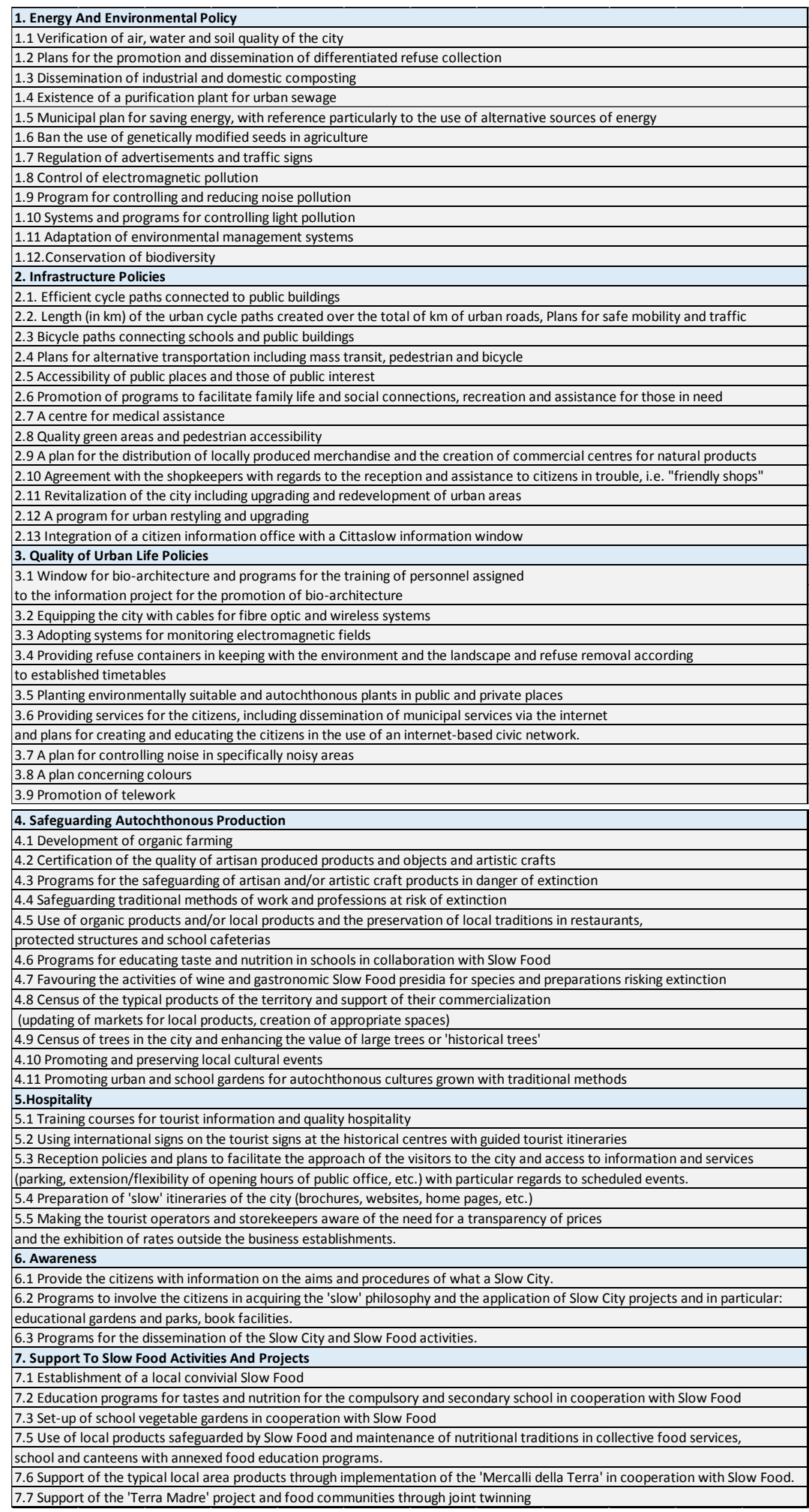

\section{Cittaslow Movement in Turkey}

Many small towns in Turkey are searching for ways to achieve sustainable development. A considerable number of them are considering tourism to stimulate economic growth (Hatipoglu, 2015). Slow-city movement first began in 2009 in Seferihisar, 
Turkey. Taking Cittaslow logo and becoming Turkey's first slowcity, Seferihisar has became "Citta-Slow Turkey" coordinator (Bilgi, 2013). Since Seferihisar was the first, other municipalities wishing to join the Cittaslow network were included in this international union, referring to Seferihisar. The following year four other towns started to work toward the Cittaslow goals. Akyaka (Muğla, Aegean Region), Yenipazar (Aydın, Aegean Region), the island of Gökçeada (Çanakkale, North Aegean Sea) and Taraklı (Sakarya, East Marmara Region) were also accepted to the network in 2011(Hatipoglu, 2015). The future aim of the local network is to further grow the network and have at least one Slow City in all seven regions of the country (Hatipoglu, 2015). There are 15 locations in Turkey until 2018, with the title cittaslow. Halfeti has this title in 2013, 9th place. As of 2018, members of Cittaslow in Turkey are shown in Table 2.

Table 2. Members of Cittaslow in Turkey (Cittaslow,2018)

\begin{tabular}{|c|c|c|}
\hline \multicolumn{3}{|c|}{ Members of Cittaslow in Turkey } \\
\hline Akkaya-Muğla & Halfeti-Urfa & Taraklı-Sakarya \\
\hline Eğirdir-Isparta & Mudurnu-Bolu & Uzundere-Erzurum \\
\hline Gökçeada-Çanakkale & Perşembe-Ordu & Vize-Kırklareli \\
\hline Gerze-Sinop & Şavşat-Artvin & Yalvaç-Isparta \\
\hline Göynük-Bolu & Seferihisar-İzmir & Yenipazar-Aydın \\
\hline
\end{tabular}

In towns that are included in the CittàSlow Network and have the capacity to provide significant resources to the national economy, the preservation of natural and historical textures is of great importance in terms of delivering these cultural heritage values to future generations as well as providing them with sustainable tourism at the national and global scale.

\section{MATERIAL}

The material of this study is the Halfeti district of Urfa, which has been declared a slow city. The study mainly focuses on observation, interviewing and analysis. SWOT analysis was conducted with local business owners by brainstorming. The results of the study are expected to be an example for the other slow cities which are similar to Halfeti district of Urfa province.

\section{Urfa - Halfeti / Turkey}

Halfeti, a district of Urfa province, was the 9th Cittaslow in Turkey. This historic and touristic city accommodates (Ekinci, 2014) 39,861 people as of 2017 . Halfeti is located on the eastern shore of the Birecik Dam Lake in the Middle Euphrates Division of the Southeastern Anatolia Region and is located in the province of Gaziantep and Urfa, bound to Urfa. Located between two big cities, 
Halfeti has an important place in terms of its location (Fig. 1). Under the influence of the Euphrates, the city of Halfeti has a particular microclimate. The environmental conditions allow many products to be grown in the district. With this advantage, the district center is in the foreground in terms of agriculture according to the surrounding districts (Boyraz \& Bostancl, 2016). Halfeti is close to a Mediterranean climate. Most of Halfeti has been submerged in water by the Birecik Dam, which was built in 2001 between Birecik and Halfeti (Fig. 2). Consequently, many inhabitants of Halfeti had to migrate or move to new settlements (Ballice, 2010). The waters of the Birecik Dam have made Halfeti the tourism center of Southeastern Anatolia within 10 years. In the district, due to the increased intensity, a general planlessness prevails. There are 17 small, but quite interesting, rock settlements lined side by side in the Savaşan village, which lies beneath the waters of Birecik Dam Lake, 3.5 kilometers north of Halfeti (Yamaç, 2015). Two of these buildings are used for touristic purposes by the tea garden on the beach. Opposite to Savaşan Village, there are numerous dwellings around Rum Kale that is located on the west Wall of Euphrates. Rum Kale is the most important historical building of this part. This castle, also named as "Hromgla" in ancient scripts, is now on a peninsula (Yamaç, 2015).

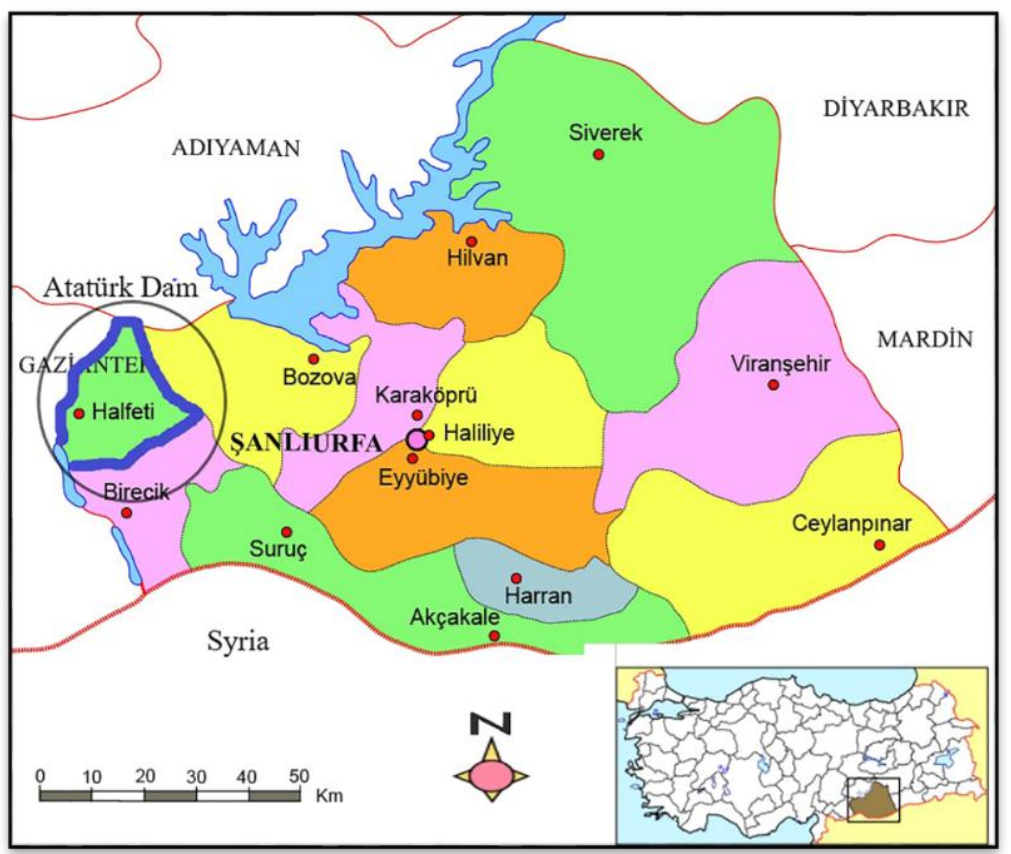

Figure 1. Location of Halfeti (Source: Boyraz \& Bostancl, 2015) 
Figure 2. Pre and post dam settlement of the former Halfeti (Source: Boyraz \& Bostancl, 2015)

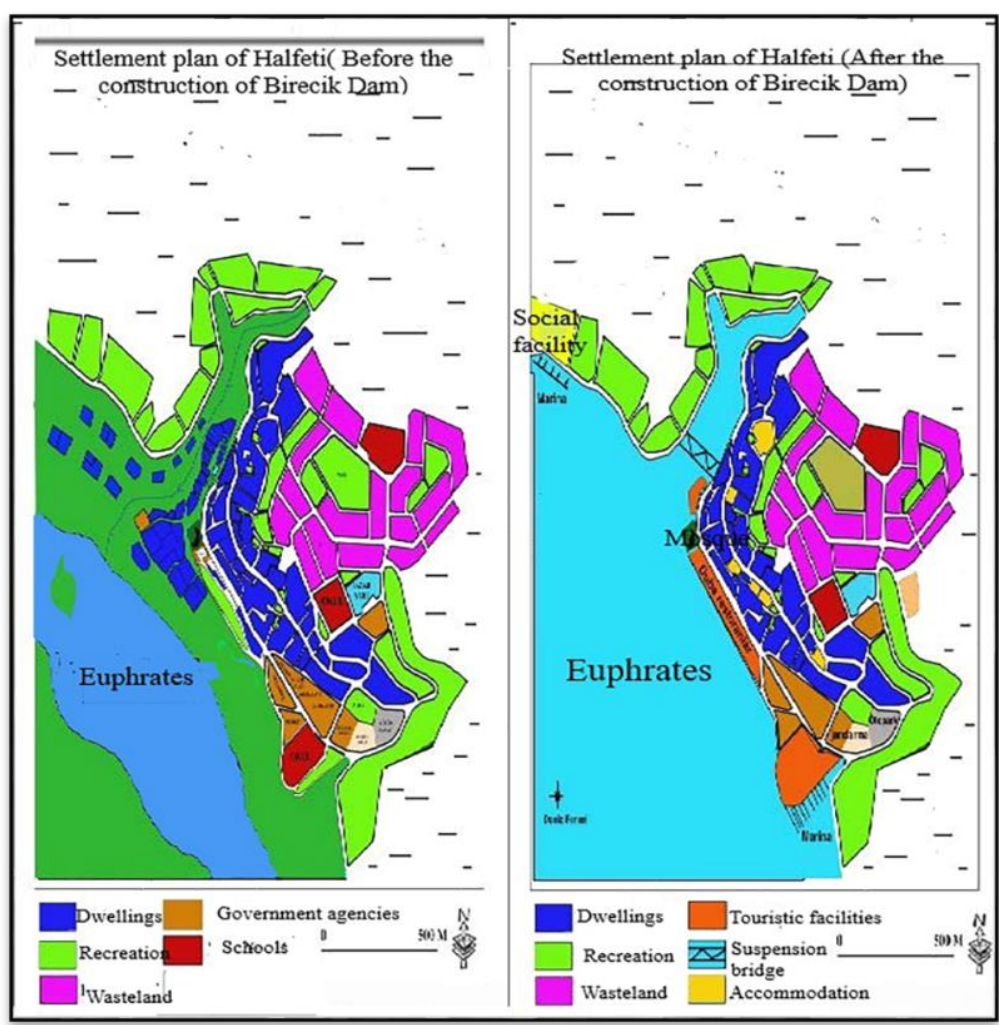

\section{Traditional Architecture in Halfeti:}

Standing like an oasis in the middle of the arid land, the original architectural texture of Halfeti is made up of two-story and garden houses made of cut stone called Nahat (means that it is obtained from calcareous stones that get harder over time) by the Armenian stone masters. The house of Halfeti, set in winding streets, form part of the landscape. Generally, two, sometimes three storey, all these houses built of white stone are adorned with elaborate stencil work (Ballice, 2010). Houses were built in an architectural layout design that would not interfere with the sight of one another (Fig. 3). Historical houses opened to narrow streets with valley slopes have not been roofed due to the effect of warm climate. This roof system, which is open on top, is called "dam". In the summer months, people sleep on the thrones set up on the dam. "Bird Houses" made for doves fed in the houses add a different originality to the traditional architecture (Fig. 4). The front of all the houses rising above the steep slopes, which dominate the Euphrates River, overlooks the Euphrates River. These houses in the Savaşan Village, a part of which are flooded and offer an exceptional view are the cultural heritages to be protected (Fig. 5). 

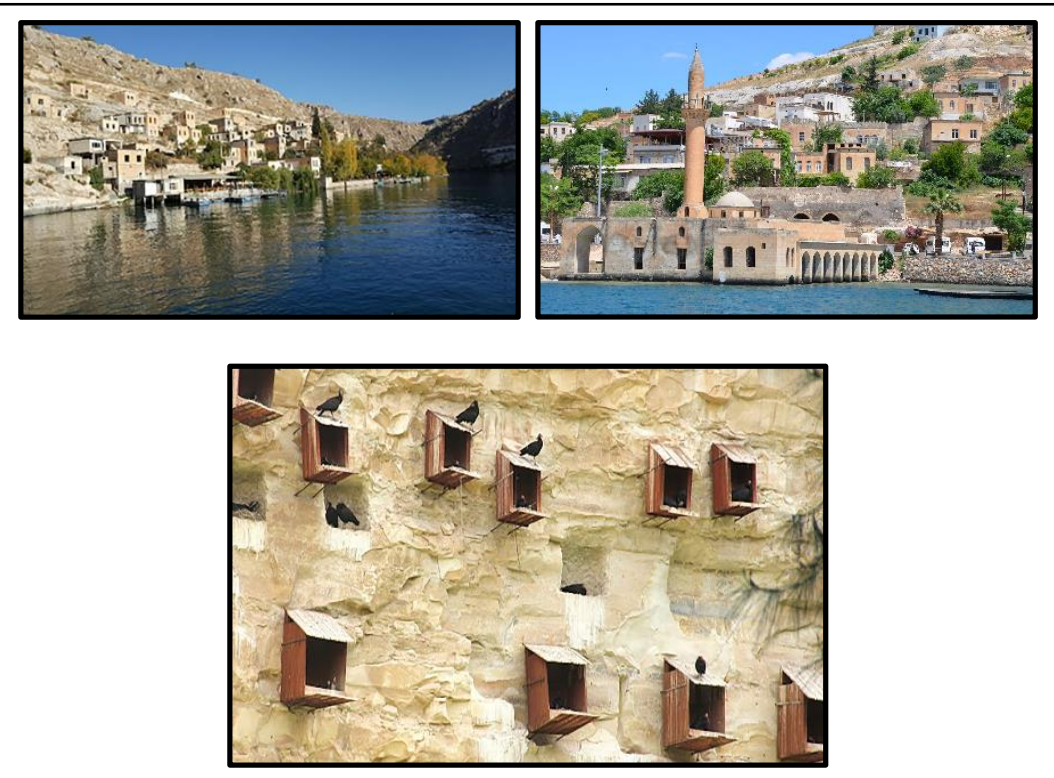

The former Halfeti settlement was set up on the western, southern and northern slopes of the "Çatal" hill, which is a barren land, where the topography shows fluctuating properties, instead of fertile alluvial lands that the Euphrates River has swept. Thus, both fertile lands were used as irrigated agriculture land, and the district center was established not on the deep valleys but on the higher slope, thus benefiting from the sun as much as possible (Boyraz \& Bostancl, 2015). The "rock church", carved from the rock on the slope opposite to the "Savaşan Village", consists of two rectangular plan sections in the east-west direction. The church, which has rock masses in the east, west and south, has a single nave and a single apse, and the northern front is open(Fig. 6). The Kaya Church, located on the eastern slope of the village 200 meters before the Euphrates River, is now on the edge of the lake. The walls of the church are made of sculpture technique and are decorated with various types of crosses in different sizes. Halfeti, which has hosted many civilizations, has an important cultural heritage. There are 96 registered cultural assets in Halfeti, 13 archaeological sites, 1 urban site and 82 registered buildings. Rumkale, located within the borders of Halfeti, where St. Nerses Church, Barsavma Monastery and many other historical buildings took place, was known as "Şitamrat" during the Assyrian period.

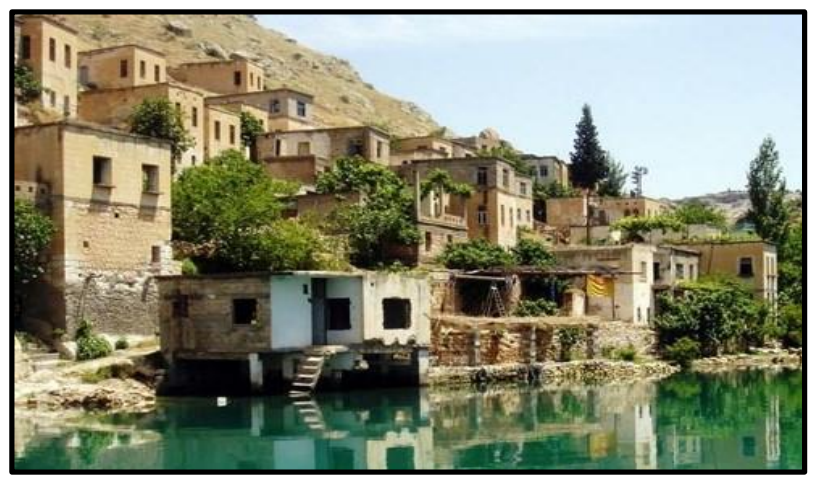

Figure 3. Settlement of dwellings (Photo: Authors, 2018)

Figure 4. Birdhouses in Halfeti (Source: Ballice, 2010)

Figure 5. General view of the Savaşan village (Photo: Authors, 2018) 
Figure 6. Savasan Village cave dwellings (Photo: Authors, 2018)

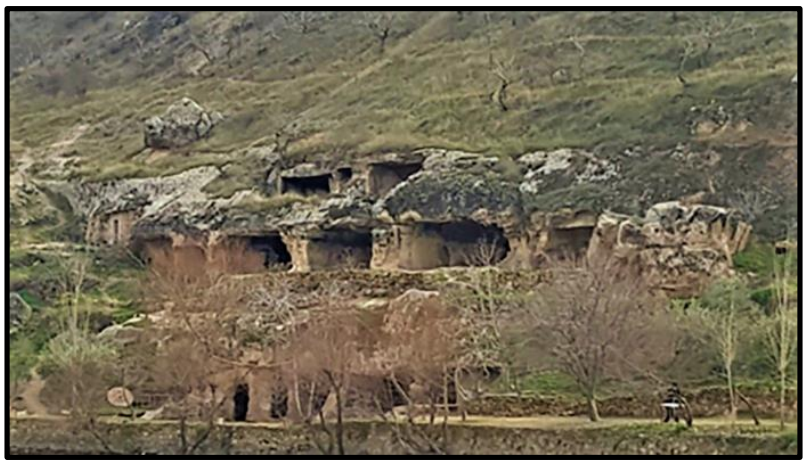

The most important examples that have been carried today from the dwelling architecture of the town are The Bey Mansion, The Muhittin Ganneci House (Fig. 7) and Feyzullah Efendi Mansion (Fig. 8). Feyzullah Efendi Historical Mansion (1901-1902), located in the Kale village due to the fact that the city is under water, was moved to Harran University Osmanbey Campus (2000-2003), 150 $\mathrm{km}$. away from the Birecik Dam within the lake boundaries. The 100-year-old stone mansion's rebuilding by transporting has been first in Turkey. The stone and wood workmanship of the building, which is located in a large garden and built in two stories as "outside sofa", "iwan" and U plan, as in traditional Turkish houses, is very smooth. Today, this mansion located within the campus of Harran University is actively used as a venue where cultural activities are held, including conference rooms, reading rooms and oriental rooms (Kürkçüoğlu, 2012). The legendary "Black Rose", which was grown in the region, has become a symbol of the city. Halfeti, with its diversity of flora and fauna, will be able to protect "Cittaslow" feature for a long time if it can maintain this diversity. The architectural and natural texture of the Halfeti district, which has hosted many civilizations, presents a visual feast to its guests who have joined boat trips, like an openair museum, after surrendering to dam waters.
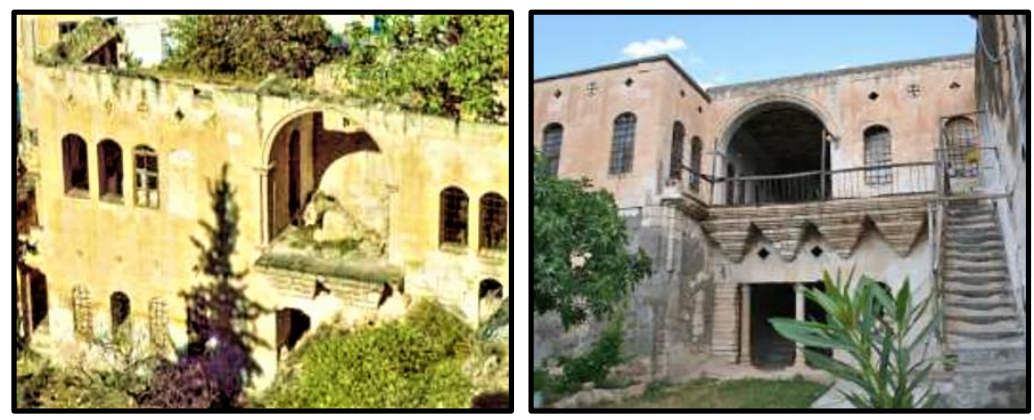

Figure 7. The Bey Mansion (left) The Muhittin Ganneci House(right) (Source: Kürkçüoğlu, 2012) 


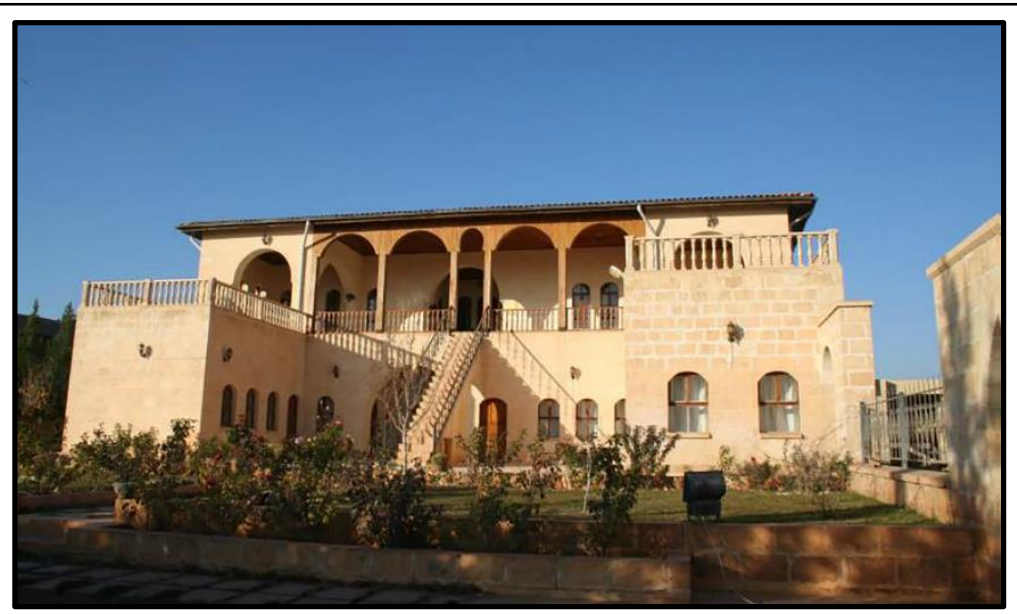

\section{New Architecture in Halfeti}

When the waters of Birecik Dam covered a large part of Halfeti in 2000, "Karaotlak" location $9 \mathrm{~km}$ away from the center of the district was established with the name "New Halfeti". The new district center, with its barren nature devoid of greenery and with esthetically deprived constructions, cannot keep the place of old Halfeti. On the other hand, the new constructed buildings in planned urban area have no identity and the new urban settlement is completely at odds with the traditional urban texture (Fig. 9).

The new settlement in Halfeti is planned on a flat area. The urban texture of the new Halfeti, with similar dimensions and rectangular forms is monotone. Apart from the superficial differences on the building facades, the apartment buildings and the streets they form are repeating each other (Fig. 10). In addition, the hotel building, which was built at a dominant point of Old Halfeti, caused great damage to the existing silhouette (Fig. 11). The irregular development of the new Halfeti puts the district's Cittaslow identity in danger.

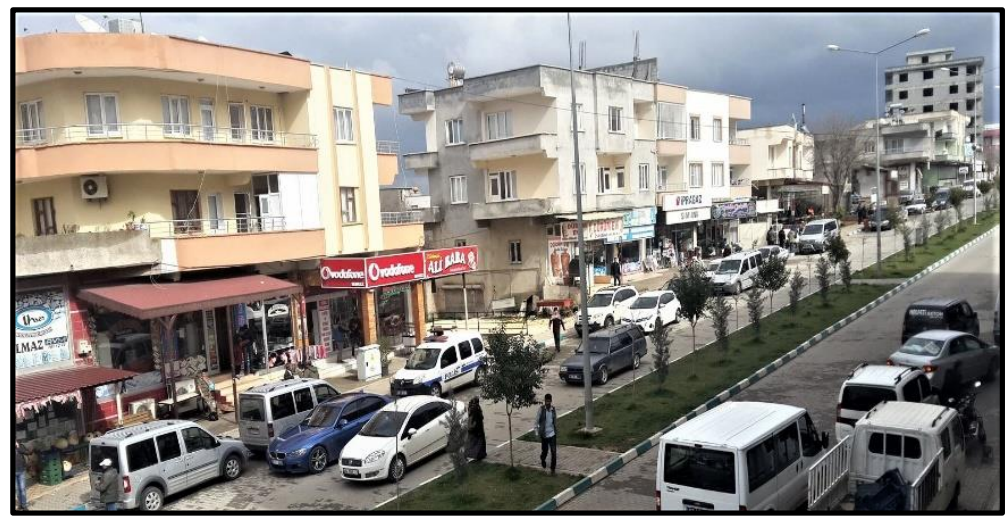

Figure 8. The Feyzullah Efendi Mansion (Source: Kürkçüoğlu, 2012)
Figure 9. Irregular buildings in New Halfeti (Photo: Authors, 2018) 
Figure 10. The general Image of the new Halfeti (Photo: Authors, 2018)

Figure 11. The hotel that damage the existing silhouette (Photo: Authors, 2018)
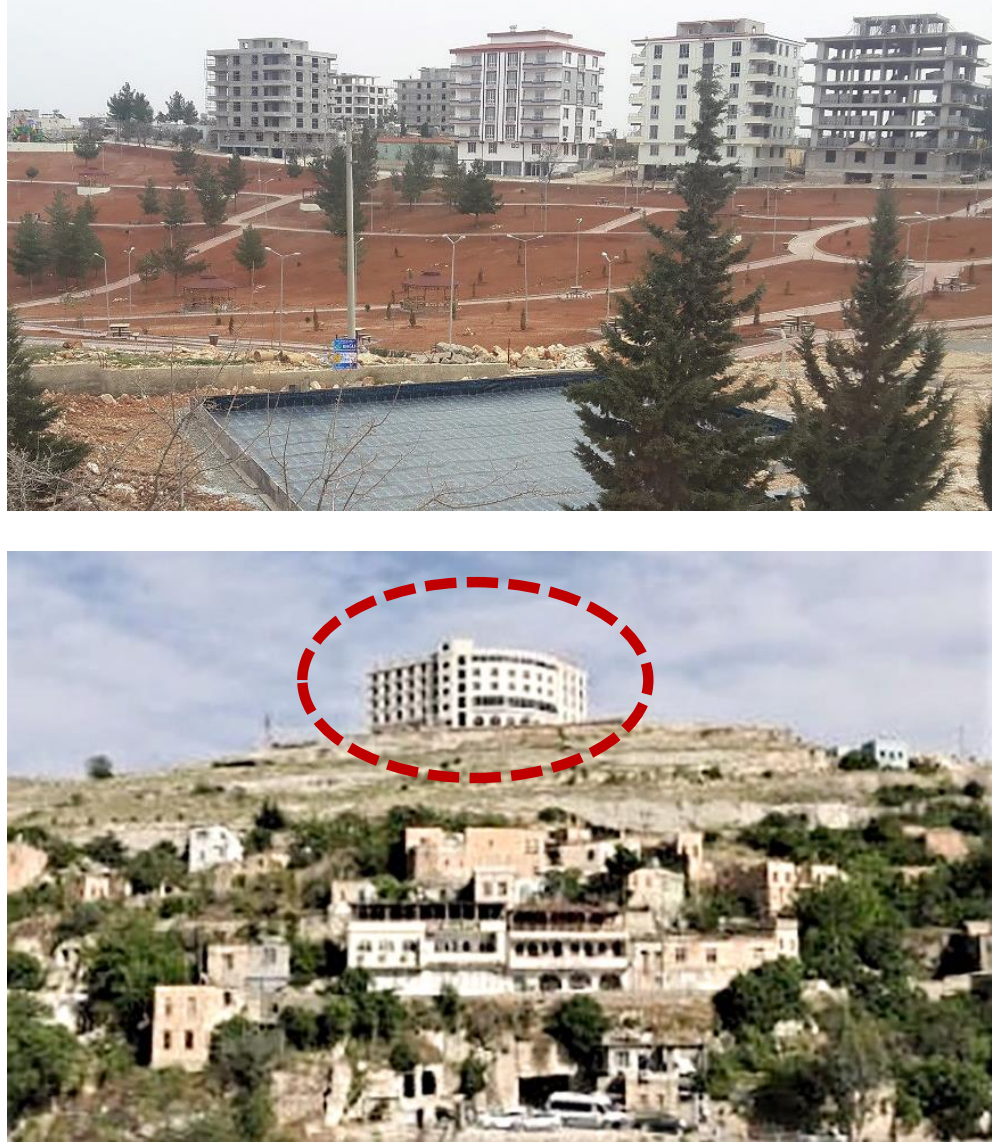

In the district, it is necessary to preserve the architecture, the traditional way of life that forms the basis of Cittaslow. In the newly created Halfeti, the basic criteria of Cittaslow must be established and implemented.

\section{METHOD}

The success of cities in today's competitive environment, where economic, socio-cultural and technological changes are intense and new performance criteria are emerging, depends on developing strategies that will maximize benefits from opportunities by identifying their strengths and weaknesses. In the study, environment and situation analysis were carried out by observation and inventory collection method in Halfeti province of Urfa declared as slow city. Using these methods, Halfeti's spatial characteristics and functional identity values were determined.

The study first sought to identify the strengths and weaknesses for the sustainable development of the Halfeti District, which was declared Cittaslow, and to identify the threats and opportunities that external environmental conditions posed. On the other hand, in the process of obtaining data within the scope of the research, the technical infrastructure of the study was established by conducting a literature search on the subject. In the light of 
collected information, assessments are grouped systematically by SWOT analysis.

SWOT Analysis is an abbreviation for strengths, weaknesses, opportunities, and threats (Özcan, 2013). In this analysis method, the positive and negative aspects of the internal and external environmental factors related to the field of the research are addressed and contributions to the decision making process are provided. The two main components of SWOT are the indicators of the internal situation described by existing Strengths and Weaknesses and the indicators of the external environment described by existing Opportunities and Threats (Markovska, Taseska, \& Pop-Jordanov, 2009). SWOT analysis is a phase in which internal and external factors are considered together to develop a strategy for a topic and the results obtained later are used in the decision-making process. This evaluation method also contributes to the development of alternative strategies in the decision making process related to the subject. In this study, a 20person group questionnaire was applied for verifying the strengths-weaknesses, opportunities and threats assessed by the SWOT analysis and ordering the outputs according to their importance. The reason for the preference of the district residents in the survey is that they should have more information about the district according to the visitors coming from the outside. This questionnaire, in which more than one choice can be marked in questions, was conducted face to face. Frequencies and percentages were used to systematically rank the importance orders of the answers of the district residents. These surveys constituted the brainstorming section of the SWOT analysis and the determined criteria were ranked in order of importance according to the questionnaire results.

\section{RESULTS AND DISCUSSION}

The demographic status of the focus group determined by the residents of Halfeti district was first revealed. The work was usually carried out at coastal enterprises. $60 \%$ of the participants consisted of men and $40 \%$ women. Men were more likely to participate in the questionnaire because of the greater number of men in the working life. In the selection of the focus group, especially those who have witnessed Halfeti's transformation process and lived in this area for a long time are preferred. For this reason, $35 \%$ belongs to the $56+$ age group, $30 \%$ belongs to the 46-55 age group, $25 \%$ belongs to the $36-55$ age group and $10 \%$ belongs to the 26-35 age group. In the questionnaires, they were asked what they were doing to determine the job opportunities available in the district. $45 \%$ of respondents have restaurant, tea garden or accommodation facility operators while $30 \%$ are tour 
guides, $15 \%$ are farming agricultural products with priority for peanut production and $10 \%$ are in the fishing industry (Table 3). Before the Birecik Dam which was built in 2000, most of the residents of Halfeti were earning their livelihood, mostly by land building. Today, most of the population is employed in tourism industry.

Table 3. The demographic situation

\begin{tabular}{llcc}
\hline Demographics & & $\begin{array}{c}\text { Freq. } \\
\text { (n) }\end{array}$ & $\begin{array}{c}\text { Percent. } \\
\text { (\%) }\end{array}$ \\
\hline \hline \multirow{2}{*}{ Gender } & Female & 8 & 40 \\
& Male & 12 & 60 \\
\hline \multirow{3}{*}{ Age } & $26-35$ & 2 & 10 \\
& $36-45$ & 5 & 25 \\
& $46-55$ & 6 & 30 \\
\multirow{3}{*}{ Occupation } & $56+$ & 7 & 35 \\
& Tour Guide & 6 & 30 \\
& Business manager & 9 & 45 \\
& Fisherman & 2 & 10 \\
\hline
\end{tabular}

The strengths of the Halfeti district in order to maintain its sustainability as a slow-city can be ranked from the most important to the least important, according to the answers given by Halfeti residents as follows. As shown in Table 4, Halfeti's most important strength is its rich cultural, natural and natural assets. Other strengths are listed in order of importance, natural resources and pristine environment, geographical location, potential tourism potential and is Turkey's ninth cittaslow settlement. Cittaslow has been said to be the lowest district by residents of the county having a county. For this reason, the fact that the "Cittaslow" phenomenon is not well known in the region has not been adequately studied.

Table 4. Strengths to continue Halfeti's sustainability as a slow city (max. three preferences) $(\mathrm{n}=20)$

\begin{tabular}{lcc}
\hline Strengths & $\begin{array}{c}\text { Freq. } \\
\text { (n) }\end{array}$ & $\begin{array}{c}\text { Percent. } \\
\text { (\%) }\end{array}$ \\
\hline \hline Geographic location & 10 & 50 \\
Rich history, culture and nature assets & 14 & 70 \\
Natural resources and pristine environment & 11 & 55 \\
To be 9 th cittaslow settlement in Turkey & 5 & 25 \\
Potential for upgradeable tourism & 9 & 45 \\
\hline
\end{tabular}

When the answers given by the residents of Halfeti are listed according to percentages, The most important opportunity of the Halfeti slow-city is the attraction of Old Halfeti, which is immersed in the waters of Birecik dam. In addition, the increase in interest in nature, history and culture tourism and the increase in awareness about preserving cultural heritage presents an important opportunity for preparation of tourism destinations for 
Halfeti District. Besides the strategic importance of the neighboring cities of Antep and Urfa, the expansion of the Cittaslow philosophy around the world and the increased interest in organic farming can be listed as extra opportunities for Halfeti.

Table 5. Opportunities to continue Halfeti's sustainability as a slow city (max. three preferences) $(n=20)$

\begin{tabular}{lcc}
\hline Opportunities & $\begin{array}{c}\text { Freq. } \\
\text { (n) }\end{array}$ & $\begin{array}{c}\text { Percent. } \\
\text { (\%) }\end{array}$ \\
\hline \hline $\begin{array}{l}\text { Old Halfeti buried in the waters of Birecik } \\
\text { dam has become tourist attraction }\end{array}$ & 17 & 85 \\
$\begin{array}{l}\text { The spread of Cittaslow philosophy in the } \\
\text { world }\end{array}$ & 6 & 30 \\
$\begin{array}{l}\text { Increased awareness of cultural heritage } \\
\text { protection. }\end{array}$ & 9 & 45 \\
$\begin{array}{l}\text { Increasing interest in nature, history and } \\
\text { culture tourism }\end{array}$ & 12 & 60 \\
$\begin{array}{l}\text { The increase in the strategic importance of } \\
\text { the neighboring cities of Antep and Urfa }\end{array}$ & 7 & 35 \\
$\begin{array}{l}\text { Increase in the given importance of organic } \\
\text { agricultural products }\end{array}$ & 3 & 15 \\
\hline
\end{tabular}

According to Table 6, the weaknesses in terms of sustainable development according to the residents of the district are; sufficient promotion and marketing can not be done, the fact that the awareness of being a slow-city is not sufficiently developed in the county, the fact that the facilities located in the districts can not do enough work in winter and the economic recession is experienced, infrastructure and service quality do not respond to needs, the inadequacy of state aid and support, lack of active local government and lack of quality in facilities established for tourists.

Table 6. Weaknesses to continue Halfeti's sustainability as a slow city (max. three preferences) $(n=20)$

\begin{tabular}{lcc}
\hline Weaknesses & $\begin{array}{c}\text { Freq. } \\
\text { (n) }\end{array}$ & $\begin{array}{c}\text { Percent. } \\
\text { (\%) }\end{array}$ \\
\hline \hline $\begin{array}{l}\text { Not enough promotion and marketing } \\
\text { In the province, awareness about Cittaslow is }\end{array}$ & 12 & 60 \\
$\begin{array}{l}\text { not sufficiently developed } \\
\text { Local government can not be active enough }\end{array}$ & 9 & 45 \\
$\begin{array}{l}\text { Infrastructure and service quality is } \\
\text { unsatisfactory }\end{array}$ & 7 & 25 \\
Inadequate state aid and support & 7 & 35 \\
In winter, facilities can not work & 9 & 45
\end{tabular}


Inadequate hygiene conditions in established facilities

As stated in Table 7, the biggest threat to the sustainable development of the Halfeti District is the irregular development of the newly established district of Halfeti. This situation seriously disturbs the residents of the district. In addition, illegal structures in the old and new Halfeti, the weakness of the touristic recognition of the county, the weakness of the zoning and building inspection and economic instabilities, threats to Halfeti's regular development and economic growth.

Table 7. Threats to continue Halfeti's sustainability as a slow city (max. three preferences) $(\mathrm{n}=20)$

\begin{tabular}{lcc}
\hline Threats & $\begin{array}{c}\text { Freq. } \\
\text { (n) }\end{array}$ & $\begin{array}{c}\text { Percent. } \\
\text { (\%) }\end{array}$ \\
\hline \hline $\begin{array}{l}\text { The irregular development of the newly } \\
\text { established Halfeti district. }\end{array}$ & 14 & 70 \\
$\begin{array}{l}\text { The continuing of illegal construction in the } \\
\text { old Halfeti and the new Halfeti region }\end{array}$ & 11 & 55 \\
$\begin{array}{l}\text { The weakness of the touristic recognition of } \\
\text { the county }\end{array}$ & 10 & 50 \\
$\begin{array}{l}\text { Economic instabilities } \\
\text { Weakness of construction and building } \\
\text { inspection }\end{array}$ & 5 & 25 \\
\hline
\end{tabular}

In Table 8, the threats and opportunities for the sustainable development of the Halfeti District are compared with the strengths and weaknesses, and the order of importance is determined and systematically ranked because of the questionnaire. The emerging picture is important to focus on strengths and address weaknesses and opportunities.

Table 8. Strengths and weaknesses, opportunities and threats for slow city Halfeti

\begin{tabular}{|l|l|l|}
\hline \multicolumn{1}{|c|}{ Strengths } & \multicolumn{1}{c|}{ Opportunities } \\
\cline { 2 - 3 } & $\begin{array}{l}\text { S1-Rich history, culture and } \\
\text { nature assets } \\
\text { S2- Natural resources and } \\
\text { pristine environment }\end{array}$ & $\begin{array}{l}\text { 01- Old Halfeti buried in the } \\
\text { waters of Birecik dam has } \\
\text { become tourist attraction } \\
\text { 02- Increasing interest in } \\
\text { nature, history and culture } \\
\text { S3-Geographic location } \\
\text { S4- Potential for } \\
\text { upgradeable tourism. } \\
\text { S5- To be 9th cittaslow } \\
\text { settlement in Turkey }\end{array}$ \\
& $\begin{array}{l}\text { 03- Increased awareness of } \\
\text { cultural heritage protection. } \\
\text { 04- The increase in the } \\
\text { strategic importance of the } \\
\end{array}$ & $\begin{array}{l}\text { neighbouring cities of Antep } \\
\text { and Urfa }\end{array}$ \\
\hline
\end{tabular}




\begin{tabular}{|c|c|c|}
\hline & & $\begin{array}{l}\text { 05- The spread of Cittaslow } \\
\text { philosophy in the world } \\
\text { 06- Increase in the given } \\
\text { importance of organic } \\
\text { agricultural products }\end{array}$ \\
\hline & Weaknesses & Threats \\
\hline 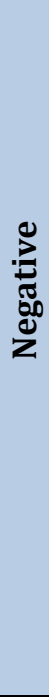 & $\begin{array}{l}\text { W1-Not enough promotion } \\
\text { and marketing } \\
\text { W2-In the province, tourism } \\
\text { awareness is not sufficiently } \\
\text { developed } \\
\text { W3-In winter, facilities } \\
\text { cannot work. } \\
\text { W4-Infrastructure and } \\
\text { service quality is } \\
\text { unsatisfactory } \\
\text { W5-Inadequate state aid and } \\
\text { support. } \\
\text { W6-Local government } \\
\text { cannot be active enough } \\
\text { W7-Inadequate hygiene } \\
\text { conditions in established } \\
\text { facilities }\end{array}$ & $\begin{array}{l}\text { T1-The irregular } \\
\text { development of the newly } \\
\text { established Halfeti district. } \\
\text { T2-The continuing of illegal } \\
\text { construction in the old } \\
\text { Halfeti and the new Halfeti } \\
\text { region. } \\
\text { T3-The weakness of the } \\
\text { touristic recognition of the } \\
\text { county } \\
\text { T4- Weakness of } \\
\text { construction and building } \\
\text { inspection } \\
\text { T5-Economic instabilities }\end{array}$ \\
\hline
\end{tabular}

\section{CONCLUSIONS AND RECOMMENDATIONS}

In this study, it was tried to determine the status of Halfeti as a tourism destination since being declared a slow city and tried to determine how to use the existing potential more efficiently by SWOT analysis method. With this study, it is revealed that Halfeti's rich history, architectural heritage, cultural and natural assets, climate and natural environment are causing visitors to attract from different regions. With the building of the Birecik dam, Halfeti, a part of which is buried under water, has become stronger in contrast to its anticipation of disappearance and has become an important center for tourism in the region. Along with the fact that it is a slow city, studies have started to protect the properties that the cities with Cittaslow title have to carry. However, it has been found that the people of the region cannot fully understand the privilege of being a slow city. The necessary initiatives to address this lack of consciousness must be made in a planned manner. The Cittaslow phenomenon must first be addressed to the people of the region and then to the visitors through advertising and promotions.

The weaknesses of the newly established Halfeti region are more oppressive than stronger directions. Irregularities and illegal buildings are the greatest threats to the regular and sustainable development of the district, which has lack of infrastructure in terms of urbanism and architecture and lack of service. It is clear 
that if the municipality cannot take precautions against this distorted development, it will have negative effects on the image of the village. In the face of these weaknesses and threats, the fact that the city has been declared a slow city is a great opportunity in terms of tourism and economic development. In addition, the recent increase in interest in nature, history and culture tourism is a strong influence on Halfeti's use of this opportunity. Parallel to tourism development in Halfeti, accommodation facilities should also be improved. Many of the accommodation in the immediate vicinity are not suitable for the mass of tourists interested in nature and culture tourism. The fact that the district of Halfeti is a member of the Cittaslow movement is very important in terms of the image of the village. In this study, it seems that the increasing demand for tourism is not ready to respond. It has concluded that Halfeti's unique identity values should be emphasized in order to be protected as a cultural heritage through the introduction on a global scale. For this reason, it is necessary for the district administration to attach importance to this issue and to develop measures in the context of sustainable urban development, keeping the current potential of Halfeti within the specified criteria. The most accurate growth strategy for Halfeti will be achieved without pollution, by preserving its natural texture and by moving to the future. Many types of alternative tourism (ecological tourism, nature tourism, culture tourism etc.) can be developed in Halfeti.

Cittaslow movement evaluated in the district of Halfeti, should be interpreted correctly and expanded nationally. In the cities where Cittaslow is declared, the places where local designs are performed should be produced respecting the nature and architectural texture. By providing more investment and capital circulation to these cities, the concept of tourism should be presented at local scales with the theme of Cittaslow. Evaluation of historical, natural, cultural and geographical beauties in conservation-use balance and reviving in tourism industry will make an important contribution to the country's development. 


\section{REFERENCES}

Ballice, G. (2010). Halfeti-Rumkale Natural Heritage from East to West (pp. 321-331): Springer.

Bilgi, M. G. (2013). Permacultural Conservation, Planning, Management and Educational Practices in the Cittaslow of Turkey. Selcuk University, Journal of the Institute of Social Sciences (29), 45.

Boyraz, Z., \& Bostancl, M. S. (2015). Tourism Potentiality of Old Halfeti (SSanlıurfa) Replaced by Birecik Dam. Journal of World of Turks, 7(3), 53-77.

Boyraz, Z., \& Bostancı, M. S. (2016). New Halfeti (Sanlıurfa) With Regard to Site of Establishment, Development and Characteristics of Function. Journal of World of Turks, 8(1), 83-107.

Charter, C. I. (2018). http://www.cittaslow.net/content/ourprinciples.

Cittaslow, (2018). http://cittaslowturkiye.org/.

Dickinson, J. (2009). Adapting tourism for a lower carbon future: A slow travel approach. Paper presented at the Transport and tourism. Challenges, issues and conflicts. Proceedings of the travel and tourism research association Europe, Annual Conference.

Doyduk, H. B. B., \& Okan, E. Y. (2016). Sustainable City Branding: Cittaslow-The Case of Turkey. Global Place Branding Campaigns across Cities, Regions, and Nations, 162.

Ekinci, M. B. (2014). Sustainable Tourism Development in Halfeti and Ayvalık as the Recent and Potential Cittaslows. Paper presented at the 9th International Conference: New Perspectives in Tourism and Hospilaty, Burhaniye, Balıkesir.

Hatipoglu, B. (2015). "Cittaslow": Quality of Life and Visitor Experiences. Tourism Planning \& Development, 12(1), 2036.

Kamel, N., Orabi, R., \& Taha, S. (2017). Slow Tourism Experience: an Innovative Approach for Sustainable Tourism development in Egypt (The case of Siwa). International Journal of Heritage, Tourism, and Hospitality, 10(2/2).

Kürkçüoğlu, S. (2012). A Coastal City in the Southeast: Halfeti. Şanlıurfa Journal of Culture and Arts History and Tourism, 13(1), 34-41.

Markovska, N., Taseska, V., \& Pop-Jordanov, J. (2009). SWOT analyses of the national energy sector for sustainable energy development. Energy, 34(6), 752-756.

Miele, M. (2008). Cittáslow: Producing slowness against the fast life. Space and Polity, 12(1), 135-156. 
Özcan, K. (2013). Protection of cultural heritage in historic towns: The experience of Birgi. Milli Folklor, 25(98), 46-58.

Radstrom, S. (2014). A Place Sustaining framework for local urban identity: An introduction and history of Cittaslow. Italian Journal of Planning Practice, 1(1), 90-113.

Semmens, J., \& Freeman, C. (2012). The value of Cittaslow as an approach to local sustainable development: A New Zealand perspective. International Planning Studies, 17(4), 353-375.

Yamaç, A. (2015). Cave Dwellings of Halfeti-Urfa (Southeastern Turkey). Paper presented at the Proceedings of International Congress of Speleology in Artificial Cavities Rome,Italy.

Yılmaz, R. (2016). Research on Slow City Movement within the Context of Sustainable Urban Planning: The Case of Vize, Kurklareli-Turkey. Global Issues and Trends in Tourism (pp. 716).

Yurtseven, H. R., \& Kaya, O. (2011). Slow tourists: A comparative research based on Cittaslow principles. American International Journal of Contemporary Research, 1(2), 9198.

\section{Resume}

Fatma Kürüm Varolgüneş, currently works at the Department of Architecture, Bingöl University. She received her B.Arch. and Ph.D. in Architecture from Selcuk University.

Fatih Canan, currently works at Konya Technical University, Department of Architecture, as an Asst. Prof. 